\title{
A QUESTION OF DEFINITION: FEMINIST LEGAL SCHOLARSHIP, SOCIO-LEGAL STUDIES AND DEBATE ABOUT LAW \& POLITICS
}

\author{
Thérèse Murphy, University of Nottingham and \\ Noel Whitty, University of Strathclyde*
}

In recent years, debate about the relationship between law and politics appears to have become a good deal more intense in the United Kingdom. As others have observed, one major catalyst for this has been the ascent of human rights in the popular imagination and in national, and international, legal and political orders. ${ }^{1}$ The problem, however, is that this development also has the capacity to skew the debate: it threatens not just the alreadyweakened claim that "law is politics" but also, if left unchecked, it could deepen the neglect of two questions that ought to be at the heart of debate about law and politics: namely, the question of law, and the question of the political.

In this article, we offer a perspective on this problem. We propose that one way of minimising it would be to have a broader definition of what counts as scholarship relevant to the question of the law/politics relationship. The redefinition we propose focuses specifically on two respected traditions in contemporary legal scholarship: the first of these is socio-legal scholarship, the second is feminist legal scholarship. The particular strength of these traditions, we suggest, is that they would encourage a broader perspective on the complexity of law and of the political. We outline the case for redefinition in Part III of the article. Prior to that, in Parts I and II, we explain what is wrong with the current "official" law/politics debate in the United Kingdom. Specifically, we identify a linked set of problems: the first is the generally-weakened status of the claim that "law is politics"; and the second is the extraordinary power of the idea of law as a system of rights and, relatedly, the fact that important concerns about this conception of law have registered far too lightly - if at all.

\section{I: "Law is Politics"?}

We begin by looking, in a general way, at the standing of the claim that "law is politics". This claim lies at one end of the conventional law/politics spectrum; the opposite end is generally described via the assertion that "law is above, or superior, to politics". ${ }^{2}$ There is also, of course, a range of more

* Our thanks to Joanne Conaghan, David Fraser and Colin Harvey for comments on an earlier version of this article.

1 For accounts of this phenomenon, see, e.g. Stevens, The English Judges: Their Role in the Changing Constitution (2002); Oliver, Constitutional Reform in the UK (2003); Steiner and Alston, International Human Rights Law in Context: Law, Politics, Morals (2000).

2 For an excellent introduction, see Loughlin, Sword and Scales: An Examination of the Relationship Between Law \& Politics (2000). 
nuanced claims: ${ }^{3}$ here we focus on the "law is politics" claim, and subsequently on its "law is above politics" counterpart, because our disquiet about the law/politics debate is linked directly to the contemporary standing of these two arguments.

The first point to note is that the claim that "law is politics" is now a shadow of its former self. Twenty to twenty-five years ago, in the first wave of critical legal scholarship (cls) in the US ${ }^{4}$ and amidst the initial impact of John Griffith's polemic in "The Political Constitution", 5 it felt fresh, full of potential and very compelling - albeit in a disquieting way. At that time, it seemed to be a genuine hard-hitter, a serious challenge to the prevailing orthodoxy: nowadays, however, it feels almost clichéd. It has become a truism and, by and large, it is greeted with routine acknowledgement. It provokes a shrug or a nod, rather than genuine engagement.

How, then, might we explain this change of status? Is it the case, for example, that "we are all crits now (just as we are all legal realists, and Keynesians)"?6 It certainly would not take long to find evidence encouraging a crit-style worldview: consider, for example, the US Supreme Court's decision in Bush v Gore (2000), ${ }^{7}$ handing the presidency of the United States to George W Bush. Or the to-ing and fro-ing around the (as yet partially-ratified) Constitutional Treaty for the European Union. ${ }^{8}$ Alternatively, one might point to the now-undeniable promiscuity of human rights claims ${ }^{9}$ and, relatedly, to the burgeoning awareness amongst liberal rights-enthusiasts that "their" rights initiatives have no "always and everywhere"10 destiny.

3 See, e.g. Abel, Politics by Other Means: Law in the Struggle Against Apartheid (1995); Dyzenhaus, Hard Cases in Wicked Legal Systems: South African Law in the Perspective of Legal Philosophy (1991); Loughlin, The Idea of Public Law (2003).

4 See the account in Kennedy, "The Critique of Rights in Critical Legal Studies" in Brown and Halley (eds.) Left Legalism/Left Critique (2002), pp.178-228.

5 Griffith, "The Political Constitution" (1979) 42 MLR 1. See also his The Politics of the Judiciary (1977).

6 Abel, Review of Bauman, Ideology and Community in the First Wave of Critical Legal Studies (2003) 30 JLS 601 at 602-603.

7 (2000) 531 US 98. See the apparent acknowledgement of this in Justice Stevens' dissent: "[a]lthough we may never know with complete certainty the identity of the winner of [the 2000] Presidential election, the identity of the loser is perfectly clear. It is the Nation's confidence in the judge as an impartial guardian of the rule of law".

8 Treaty Establishing a Constitution for Europe CIG 87/2/04 Rev. 2, Brussels, 29 October 2004.

9 That is to say, the ways in which rights have become the language of choice for a radically diverse, often oppositional and expanding range of social movements: see, e.g. Goldberg Hiller, “'Subjectivity is a Citizen': Representation, Recognition and the Deconstruction of Civil Rights" (2003) 28 Studies in Law, Politics, and Society 139 at 173 describing the rise of an "equal rights, not special rights" idiom amongst US groups opposed to gay marriage and noting that these arguments "invert the nature of harm and redefine majorities as victims of anarchic demands and as authentic rights subjects".

10 Kennedy, The Dark Sides of Virtue: Reassessing International Humanitarianism (2004), pp.32-33. 
But other explanations for the change in status of "law is politics" also merit consideration, not least because they might help to provide a fuller understanding of the ebb and flow of the claim. One such explanation is that the downturn in fortune can be attributed, at least in part, to the fact that some of those who have made this claim failed to follow-through on their own argument. In other words, reliance in the past on "law is politics" as a conclusion rather than a starting-point could be to blame for the broad but superficial following that the claim receives today. Rick Abel makes this exact criticism in reviewing the history of critical legal scholarship in the United States, pointing out that the argument that "law is politics" cannot serve (nor was it ever designed to serve) as more than the entry-point for inquiry into the interesting questions, such as "the consequences of emphasizing or denying the unity [between law and politics]". ${ }^{11}$

Another explanation for the change in status can perhaps be found in the fact that both cls and the Griffith tradition in English public law - two groupings traditionally associated with the argument that "law is politics" - are generally categorised as "left" theories, and left theories have a popular (if largely unfair) reputation for being heavily totalising. In other words, part of the reason for the weakened status of the "law is politics" claim could be reluctance to become associated with a broader left project, or mindset, allegedly lurking behind it. And, looking specifically at the Griffith tradition in English public law, a further related explanation comes to mind: this oncepowerful tradition has recently been in disarray. Much (though not all) of its repertoire has been castigated as overly-familiar and insufficiently-attentive to the changed circumstances of contemporary governance. David Dyzenhaus, for example, has described the tradition - which he labels "left public law" - as beset by problems of adaption. ${ }^{12}$ Its proponents, Dyzenhaus argues, have come across as unsure about how best to respond "in the face of its loss of purchase on control of parliamentary politics and the more general decline in parliament as the main engine of politics". ${ }^{13}$ This uncertainty has, he says, been accompanied by a tendency towards "an abandonment of hope in a principled approach to questions of social justice, a resort to tradition in a bid to ground the substance of political identity, and the thought that the executive is the guardian of the political constitution in that it is for the executive to decide how to resolve the existential conflicts of politics". ${ }^{14}$ The fact that judges in the Human Rights Act era do not always live up to the "left public law" stereotype has been another problem for the tradition: so, for example, the Law Lords' opinion in A and Others v Secretary of State for the Home Department (2004), ${ }^{15}$ declaring the internment of terrorist suspects

11 See n.6 above. Abel suggests that the "interesting questions" include: "Does it affect who are appointed as judges? How they decide? How they justify those decisions? Others' willingness to comply? General respect for state authority?"

12 Dyzenhaus, "The Left and the Question of Law" (2004) 17 Canadian J of Law and Jurisprudence 7.

13 ibid.

14 ibid., at p.24.

15 [2004] UKHL 56. But note Lord Bingham's account of the judicial role and the law/politics divide: "it is the function of the political and not judicial bodies to resolve political questions. Conversely, the greater the legal context of any issue, the greater the potential role of the court, because under our constitution and subject to the sovereign power of Parliament it is the function of the courts and not 
unlawful, would seem to provide an effective retort to the Griffith-esque taunt that, "particularly in times of crisis", judges will fail to protect "the individual who comes face to face with the state". ${ }^{16}$ More generally, it surely does not help that legislatures and traditional conceptions of democracy have dropped down discussion agendas amidst a frenzy for the common law, courts and all things adjudicative. ${ }^{17}$

A fourth explanation might go as follows: the claim that "law is politics" is out of step with a powerful contemporary impulse - the impulse to protect law. We believe that this protective instinct can be traced to a number of sources. One such source is the age-old enthusiasm for treating law as distinctive: in short, the "great imaginative sway"18 in law's claim to impartiality continues to influence almost all of us. Another is the fact that, in legal circles, law's formal qualities have been acquiring new advocates. These advocates emphasise the importance of law's formalism whilst remaining totally alert to law's political nature: see, for example, David Dyzenhaus' argument that, although "law may be 'politics by other means", it is nevertheless "politics under the constraints of legal order, constraints which impose conditions of publicity, obligations to justify official decisions, and a general obligation on judges to find a role for themselves as the enforcers of legality, not just of positive law". ${ }^{19}$ Amongst academic lawyers, this sort of advocacy could well have bolstered the enthusiasm for treating law as distinctive. More importantly, by exploring how law's formal qualities can be flawed but indispensable, it has surely made the claim that "law is politics" considerably less attractive.

The waning popularity of "law is politics", and the rise of the protective instinct towards law, may also be linked to another recent trend in academic circles: namely, the outpouring of commentaries on "the politics of ..." - for example, the politics of nature, the body, culture, economics, the social, the domestic or the intimate. It seems likely that, amidst this "dispersion of the political", ${ }^{20}$ the claim that "law is politics" became less interesting. To put it crudely, if everything is political, then nothing is political. Or, at the very least, the claim that "law is politics" is likely to register as pedestrian or nondescript. Moreover, having observed the way in which anthropologists, economists, literary theorists and others became "experts" on the political, thereby crowding the space once occupied almost exclusively by political theorists, academic lawyers may well feel (even) more inclined to argue for

of political bodies to resolve legal questions' (para.29). On the question of the "political", see below 553-556.

16 Ewing, "The Futility of the Human Rights Act" [2004] PL 829 at 840. More generally, see Lord Justice Sedley, "The Rocks or the Open Sea: Where is the Human Rights Act Heading?" (2005) 32 JLS 3 at 17 arguing that "we are making headway".

17 For an argument that the legislature's role merits greater attention than it is receiving, see especially, Waldron, The Dignity of Legislation (1999).

18 Loughlin, n.3 above, p.52.

19 Dyzenhaus, "The Difference That Law Makes" (1997) 60 MLR 866 at 873. See also Harvey, "Playing with Law and Politics" (2001) 51 University of Toronto LJ 171; Koskenniemi, The Gentle Civilizer of Nations: The Rise and Fall of International Law 1870-1960 (2001).

20 See generally, Brown, "At the Edge" (2002) 30 Political Theory 556. 
the distinctiveness of law (and, hence, the authority of lawyers) in an effort to guard the boundaries of their own discipline.

The current level of protectiveness towards law can also be traced, we suggest, to the fact that, in accepting that law is politics, one often ends up feeling that insufficient room has been left for faith - whether faith in law in general or, more narrowly, faith in the now-popular idea of law as a system of rights. This form of faith is widespread, deep-rooted and hugely resilient. Basically, once you admit the possibility that law could be (or sometimes has been) a tool of progressive social change - albeit a complex and contradictory one - it becomes difficult to square this with a stark "law is politics" vision of legal reasoning and of rights. Not surprisingly, faced with this problem, most of us will pull back from the stark claim that "law is politics". After all, why concede the potential power of law - no matter how treacherous or transient - to others? Is there not a risk, as Colin Harvey argues in light of the history of the Northern Ireland conflict, ${ }^{21}$ that denuding legality could hurt, and in serious not superficial ways?

In our view, the risk of conceding the potential of rights is now being felt in a particularly acute way. To begin with, there is the fact that it is very difficult to resist the evangelism of contemporary rights enthusiasm. There are also cherished histories of rights' revolutions (e.g. the 1960s in the US), as well as nascent rights' challenges, that seem to call out for recognition and support. Indeed, in making an argument against faith in rights, the cls scholar Duncan Kennedy acknowledges that rights talk benefits greatly from the fact that it is connected to daring, specifically "to daring to claim things on a basis that might previously have been disqualifying, to claiming things for blacks, women, gays, or Hispanics, when the feeling before might have been that because one was one of these things one was disentitled to make claims". ${ }^{22}$ Kennedy also points out that rights talk profits from the widespread feeling that "if "we' lose our faith in rights rhetoric but 'they' don't, then they will gain an advantage over us". And, as he acknowledges, this feeling is entirely understandable given the "sense of righteousness, of mediation, that rights have historically provided":

'Giving up' rights would be like a professional athlete giving up steroids when all his or her competitors are still wedded to them. ${ }^{23}$

There is one final point that deserves mention before we conclude this discussion of the protective instinct towards law: namely, there seems to have been an increase in depictions of law as an essential corrective - or, in Abel's words, of law as a "port in the storm". ${ }^{24}$ The reasons for this increase are manifold: they include, first, the frequency of news stories describing political corruption, patronage and spin, thereby intensifying the understanding of politics as an arena of troubling passions and motives; secondly, the fact that the perennial hunger for constraints on the powerful is stronger in an era of global power; and, thirdly, as we discuss in the next section, the spread of rights talk and the associated "globalization" of

21 See n.19 above.

${ }^{22}$ See $\mathrm{n} .4$ above, at p.214.

23 ibid., at p. 217.

24 See n.6 above, at p.608. 
human-rights lawyering. ${ }^{25}$ Of course, whatever the reasons, the key point for present purposes is that increasing interest in the idea of law as a "port in the storm" is likely - as a general rule - to be tied to a downturn of interest in the claim that "law is politics".

\section{II: The Ascent of Rights}

In this section, we focus on one of the points mentioned above: namely, the force and scale of contemporary rights enthusiasm. As others have observed, rights enthusiasm has already had a huge impact on debate about the law/politics relationship. Specifically, the ascent of the idea that law (or, more specifically, human rights law) provides universal principles that can, and should, govern the conduct of politics has given new power to the claim that "law is above politics". ${ }^{26}$ Part of this power comes from the fact that there are some extremely sophisticated versions of rights enthusiasm: Ronald Dworkin's acknowledgement that "law is argumentative" has, for example, made it far more difficult to mount a "law is politics"-type challenge to the argument that law (as rights) is superior to politics. ${ }^{27}$ But, as we argue below, at least in the UK the power may also come from the fact that, in public-law circles, debate between critics and proponents of the ascent of rights tends to revolve around a specific, relatively narrow set of issues. Our concern is that this is distorting debate about law and politics: specifically, important and challenging questions about the idea of law as a system of rights - questions concerning underlying conceptions of law, and of the political - are often left unasked.

In Part III, we suggest that the distortion could be reduced by broadening the terms of engagement through the use of strands of legal scholarship that, hitherto, have largely been neglected in the acknowledged or "mainstream" debate about law and its relationship to politics. First, however, we need to examine the phenomenon itself: that is, the widespread reorientation of legal and political orders, and of the popular imagination, towards the idea of law as a system of rights.

\section{Law as a System of Rights}

The first key point to note is that the ascent of rights is multi-dimensional. Institutions of governance are affected; so too are public and professional

25 See, e.g. the observation by Murphy, Review of Luhmann, Law as a Social System (2005) 25 LS 520 at 522: "But lawyers around the world have now snuggled in to a perspective of moral superiority in relation to politicians and others; upholding the rule of (international and national) law is now presented as paramount (with these lawyers as their champions). A mish-mash of human rights, morality and legal technicalities is offered, vociferously and voluminously, as the solution to our troubles and as the new regles $d u$ jeu for politics, international finance and so on." Cf. Riles, "Anthropology, Human Rights, and Legal Knowledge: Culture in the Iron Cage" (2006) 108 American Anthropologist 52, arguing that the professional lives of a range of human rights actors are defined by "a subtle agnosticism", that is, by a "set of questions and concerns about human rights practice".

${ }^{26}$ For an introduction to this phenomenon, see, e.g. Loughlin, n.2 above.

27 But for an example of one such challenge, see Hutchinson, It's All in the Game: A Nonfoundationalist Account of Law and Adjudication (2000). 
consciousness. We are, as Neil Walker points out, in the midst of the 'institutionalisation and internationalisation of the idea of law as a system of rights which frames and contains government power. .. ${ }^{28}$ The potential for rights to constrain private power also seems to be gaining momentum. Evidence of these trends is everywhere. Most obviously, charters of rights are currently a pre-eminent feature of democratic transition around the world, and insistence on the protection of human rights has become both a mantra of global governance (see, for example, the standard positions of the UN or the IMF) and an alleged cornerstone of Western foreign policy. ${ }^{29}$ Second, many existing rights regimes are widely considered to be flourishing: South Africa and Canada are perhaps the best-known examples. In addition, in Europe, the expansion of the Council of Europe and the reach of the ECHR, and the European Union's adoption of a charter of fundamental rights in its proposed Constitution, are widely seen as further evidence that protection of rights is an essential component of the "European project".

The ascent of rights is also strongly in evidence in the academy and in popular consciousness. In academia, advocacy of rights has been a theme in the work of a number of prominent figures who have had significant crossover or popular appeal. Three notable examples are Ronald Dworkin, John Rawls and Patricia Williams. ${ }^{30}$ Moreover, although these individuals differ in their preferred approaches to rights, their work (and that of other theorists who are pro-rights) tends to function in combination in a way that assists the ascent of rights and makes criticism of the phenomenon a great deal more difficult: "[a]ll show that philosophy, something at once higher than, more intellectually sophisticated than, and also more determinate than postrealist text-based constitutional argument, supports legalizing liberal rights claims". ${ }^{31}$

That said, it is in public consciousness, rather than in academia, that rights talk features most strongly. As noted earlier, rights now provide the language of claims-making. And they provide this language not just for activists, advocates and victims who seek to engage the power of law but also for the "everyday": in short, as Duncan Kennedy has pointed out, rights have seeped into "just about every milieu where people argue about who should do what". 32

\section{The Ascent of Rights \& the Law/Politics Debate}

Not surprisingly, there is already a wide range of scholarship commenting on the ascent of rights. This scholarship includes accounts that welcome or

28 Walker, Review of Loughlin, Sword \& Scales: An Examination of the Relationship Between Law \& Politics [2001] PL 644, at 646.

29 For criticisms of these trends, see Kennedy, n.10 above; Robertson, Crimes Against Humanity: The Struggle for Global Justice (2002); Sands, Lawless World: America and the Making and Breaking of Global Rules (2005).

30 See, respectively, Dworkin, Taking Rights Seriously (1977); Dworkin, Freedom's Law (1996); Rawls, The Law of Peoples (1999); Williams, The Alchemy of Race and Rights (1991).

31 Kennedy, n. 4 above, at p.180.

32 ibid. 
anticipate the alleged triumph of rights. ${ }^{33}$ In starkest contrast to these, are the accounts that declaim the ascent of rights (and, in particular, the positivisation of rights) as the end of human rights, ${ }^{34}$ or espouse a deep cynicism about the enthusiasts' claims. $^{35}$ There is also an established body of sceptical accounts, with some sceptics seeing the detail of the positivisation of rights as key - specifically, whether or not the form chosen permits legislative override, which is seen as essential for 'dialogue' between courts and legislatures. ${ }^{36}$ In addition, there are accounts that express qualified or cautious optimism for charters of rights. ${ }^{37}$ Finally, there is a set of accounts that can be grouped together under the heading of "critical pragmatism". ${ }^{38}$ The scholars who produce these latter accounts tend to share a view of rights as "paradoxes" 39 and, in line with this, they endorse the use of rights but emphasise the need for ongoing vigilance as regards the constraints that can be produced by rights claims. ${ }^{40}$ In other words, critical pragmatists work with or "do" human rights but this activity is placed intentionally and explicitly - in a form of ongoing tension with their critique of rights.

For present purposes, one particular allegation about the ascent of rights is of special interest: it concerns the views of law and of politics that are seen as grounding, and as fostered by, rights enthusiasm. The core of the allegation is that the institutionalisation of rights has led to a disturbing juridification of national and global politics. Duncan Kennedy, one of those making this allegation, uses stark language to convey his concerns: "the rule of law and rights seem to function as crucial paradigms of rightness for everyone. There has been a kind of concentration of experiences of rightness into the two contrasts of law versus politics and rights versus mere preferences". ${ }^{41}$ Martin Loughlin has been equally forthright, describing the developments as the legalisation of politics and the politicisation of law. ${ }^{42}$

33 See, e.g. Klug, Values for a Godless Age: The Story of the UK's New Bill of Rights (2000); Williams, The Case for an Australian Bill of Rights (2004).

34 Douzinas, The End of Human Rights: Critical Legal Thought at the Turn of the Century (2000).

35 See, e.g. Arthurs, "Constitutional Courage" (2004) 49 McGill LJ 1; Ewing, n.16.

36 See, e.g. Campbell, Ewing and Tomkins (eds.), Sceptical Essays on Human Rights (2001).

37 See, e.g. Gearty, Principles of Human Rights Adjudication (2004); Feldman, "The Impact of Human Rights on the UK Legislative Process" (2004) 24 Statute LR 91; Hogg and Bushell, "The Charter Dialogue Between Courts and Legislatures (Or Perhaps the Charter of Rights Isn't Such a Bad Thing After All)" (1997) 35 Osgoode Hall LJ 75; O'Cinneide, "Democracy, Rights and the Constitution: New Directions in the Human Rights Era" [2004] CLP 175.

38 This is only one of a number of labels used to designate this grouping, and not all of those who identify with the characteristics we outline would choose this term.

39 See, esp, Brown, "Suffering the Paradoxes of Rights" in Brown and Halley, n.4 above, pp.420-434.

40 See, e.g. Herman, "Beyond the Rights Debate" (1993) 2 SLS 25; Stychin, A Nation By Rights: National Cultures, Sexual Identity Politics and the Discourse of Rights (1998); Whitty, Murphy and Livingstone, Civil Liberties Law: The Human Rights Act Era (2001).

41 See n.4 above, at p.219.

42 See n.2 above, at pp.232-233. 
A related allegation accuses rights' enthusiasts - particularly international ones $^{43}$ - of being caught up in a dangerous sense of self and of mission. Michael Ignatieff is one of those who has made this criticism: "[h]uman rights activism likes to portray itself", he says, "as an anti-politics, in defense of universal moral claims designed to delegitimize 'political' (i.e. ideological or sectarian) justifications for the abuse of human beings." 44 The attitude of rights' enthusiasts has also been criticised by the international lawyer, David Kennedy. Overall, Kennedy is more optimistic than Ignatieff about the future of rights professionalism, but he does accuse international humanitarianism of being "tone deaf to the specific political consequences of its activity in particular locations, on the mistaken assumption that a bit more human rights can never make things worse". ${ }^{45}$ And he reminds all those who are tempted by rights that there is no "always and everywhere" destiny of human rights initiatives: indeed, he suggests that "it may be that all we have is a list of possible downsides, open risks, bad results which have sometimes occurred, which might well occur". ${ }^{46}$

In essence, then, the argument being made by all of these critics is that the widespread institutionalisation of rights, in a climate of unreflexive rights enthusiasm, is encouraging an impossible idea of law and adjudication: an understanding of law as autonomous from, and contrasting with, the messy particularity of politics - of law as the essential and effective constraint upon the political. For present purposes, what interests us most about this argument is its relatively limited impact: specifically, why has it not made more of a dent in the status of the claim that "law (as rights) is above politics"? 47

Part of the explanation perhaps is that this criticism is pitted against an extraordinarily powerful trend. But we want to suggest that it is also because, in public law circles in the UK, debates about rights, and about law and politics generally, tend to be dominated by a specific and relatively narrow set of concerns. For example, commentators will often define their concerns in ways that speak only to those possessing specialised knowledge of a particular subject area - say, rights constitutionalists, or European lawyers. Moreover, within these subject areas, debate is sometimes marked by an

43 See, e.g. Kennedy n.10 above, at p.xiv describing "a posture or sensibility" exhibited only by the internationalist - typically, a dedication to "the international itself". Some see this posture as an asset, but for Kennedy and others it is a cause for concern: see, e.g. Mutua, Human Rights: A Political and Cultural Critique (2002), arguing that "many in the human rights movement mistakenly claim to have seen a glimpse of eternity ... This view is so self-righteous and lacking in humility that it of necessity must invite probing critiques from scholars of all stripes"; and Harlow, "Public Law and Popular Justice" (2002) 65 MLR 1 at 17 reflecting on the English context and criticising an international human rights lobby "which will not stop pushing until the door is wide open" and the legal process has been transformed into a "free-for-all".

44 Ignatieff, Human Rights as Politics and Idolatry (2001), at p.9.

45 See n.10 above, pp.33-34.

46 ibid.

47 Note, however, the influence of neo-conservative thinking on the perceived threat to US political power by a globalizing human rights agenda: see further, Mansell and Haslam, "John Bolton and US' Retreat from International Law" (2005) 14 SLS 459 . 
even more disorienting level of specialisation - "deep insiderism" might be a good way to describe it. ${ }^{48}$ These tendencies are understandable. And they are, to some extent, unavoidable. But their downside is that the argument that "law (as rights) is above politics" has tended to get an easier ride as some concerns have become over-dominant (thereby blocking out others) and others have failed to migrate from one specialisation to another (thereby limiting their power).

It could be argued that some of these problems flow from the narrow definitions of adjudication that continue to dominate the public law literature. For example, accounts of Human Rights Act jurisprudence have been particularly animated about the importance of identifying, and constraining, judicial "activism". In particular, commentaries on section 3(1) of the Act ${ }^{49}$ have sought to establish a definitive construction of the judicial role, with a recognisable boundary between the (legitimate) task of "interpreting" and the (illegitimate) task of "legislating". ${ }^{50}$ Academic responses to the revival of a common law rights-based constitutionalism have followed a similar pattern, with little attention being paid to how and why judges construct the law/politics distinction in individual cases. ${ }^{51}$

Our concern then is that the nature of debate on law and politics in public law circles could be part of the explanation for the remarkable power of the claim that "law (as rights) is above politics". To put it crudely, and accepting also that there are notable exceptions, the claim is not being met by a sufficient level of challenge. There is not, in other words, enough of a range of challenges and, in addition, the very precise, almost technical focus of certain existing challenges means that common underlying concerns can feel submerged by detail. That said, there is evidence pointing towards the development of new forms of engagement. There is, for example, obvious support for Jeremy Waldron's suggestion that more direct attention needs to be paid to legislative processes and traditional conceptions of democracy. ${ }^{52}$ The burgeoning public-law profile of legal pluralist scholarship on the one hand, and transitional justice scholarship on the other, also augur well for the development of a fuller range of challenges. In fact, legal pluralism's

48 In the English public law context, a notable example of this is provided by the ongoing dispute between two leading scholars on their understandings of the constitutional foundations and limits of judicial review: see Allan, "Legislative Supremacy and Legislative Intent: A Reply to Professor Craig" (2004) 24 OJLS 563 and Craig, "Legislative Supremacy and Legislative Intent: A Reply to Professor Allan" (2004) 24 OJLS 585.

49 S.3 provides that: "So far as it is possible to do so, primary legislation and subordinate legislation must be read and given effect in a way which is compatible with the Convention rights".

50 See, e.g. the discussion in Young, "Ghaidan v Godin-Mendoza: Avoiding the Deference Trap" [2005] PL 23; Hickman, "Constitutional Dialogue, Constitutional Theories and the Human Rights Act 1998" [2005] PL 306.

51 See Hutchinson, Evolution and the Common Law (2005) for a wider critique of the development of the common law, arguing that most judges and jurists remain united in "demonstrating that not only can the common law balance the competing demands of stability and change, but can do so in a legitimate way that respects the important distinction between law and politics" (p.10).

52 See, e.g. Tushnet, "Non-Judicial Review" (2003) 40 Harvard J on Legislation 453; Tomkins, Our Republican Constitution (2005). 
capacity to problematise the question of law seems particularly promising: as Gavin Anderson has pointed out, the reason for this is that "[f]or most lawyers, the question of law never arises - according to the dominant paradigm of liberal legalism, law is exclusively state law, made by legislatures or pronounced by courts. Moreover, it is simply assumed that law is a coherent system of norms that operates directly on society as a tool of social engineering" ${ }^{53}$

As mentioned above, transitional justice is another promising and increasingly-acknowledged source. Broadly speaking, transitional justice scholarship is characterised by very direct engagement with the question of the relationship between politics and the (now-powerful) understanding of law as rights. Think, for example, of the work on Northern Ireland that is being done by Christine Bell et al, Colin Harvey and Kieran McEvoy. Their scholarship promises to add very considerably to current understandings of law as a system of rights: it explores, for example, the risks of deformalisation that attach to an unthinking "cult" of rights (e.g. the dangers that could result from widespread popular support for the idea that judges are no longer simply to apply the law but to protect rights); the ongoing negotiations that are involved in a culture of rights' claims and counterclaims; the attitudes of non-state protagonists (e.g. paramilitary prisoners) towards law (and, more particularly, law as a system of rights) during the Northern Ireland conflict; and the pros and cons of different ways of dealing with past atrocities (e.g. individual prosecutions vs. inquiries or truth commissions) when building a new society. ${ }^{54}$

That said, in concluding this article, we want to draw attention to other established strands of legal scholarship which continue to be neglected or under-used in discussions on law and politics and which we contend can fruitfully broaden the terms of the debate. The two particular legal traditions we have in mind are, first, feminist legal scholarship and, secondly, sociolegal studies.

\section{III: A Question of Definition}

In our view, socio-legal studies and feminist legal scholarship have been peripheral to the mainstream law/politics debate because of a problem of framing or definition. In the case of the latter, the neglect seems to have been produced by the framing of legal feminism as a form of "identity politics", which has led in turn to the assumption that - at best - its contribution to a

53 Anderson, Constitutional Rights After Globalization (2005), p.39. Anderson's own work provides a good example of the fundamental nature of the challenge presented by legal pluralism: he has targeted the dominant liberal legalist form of constitutionalism, arguing for a "paradigm shift" to a new legal pluralist constitutionalism which, he says, offers both a better explanation of political power and law in a globalised world and a better starting-point for holding private power - for example, transnational corporations - to account.

54 See, e.g. Bell, Campbell and Ní Aoláin, "Justice Discourses in Transition" (2004) 12 SLS 305; Harvey, "On Law, Politics and Contemporary Constitutionalism" (2003) 26 Fordham Int LJ 996; McEvoy, "Beyond the Metaphor: Political Violence, Human Rights and 'New' Peacemaking Criminology" (2003) 7 Theor Crim 319. See also Atria, "The Time of Law: Human Rights Between Law and Politics" (2005) 16 Law and Critique 137. 
law/politics discussion would be limited to insight on specialist aspects of the topic of "law as a system of rights". That said, the neglect has perhaps been compounded by the fact that legal feminists have not engaged sufficiently (or at least sufficiently explicitly) with the central concerns animating mainstream constitutionalism. ${ }^{55}$ As regards socio-legal studies, the neglect feels less pronounced but, as we suggest below, it is still problematic. Here the neglect seems to arise from the fact that socio-legal scholarship continues to be placed in a largely technical, supporting role: it remains, in other words, the policy-maker's or theorist's "little helper", ${ }^{56}$ and its core questions on law "in action", as well as its endorsement of empirical inquiry, continue to be seen as marginal to mainstream constitutional law and theory. But, as with feminist legal scholarship, here too it might be argued that the neglected party also bears a certain responsibility. It could, for example, be argued that the relatively low level of dialogue between socio-legal scholars and comparative lawyers in recent decades ${ }^{57}$ meant that an opportunity for sociolegal studies to reach out to a constitutionalist audience by using overlaps with comparative law as a common link (and, hence, a potential "icebreaker") was wasted. ${ }^{58}$ More generally, as with feminist legal scholarship, socio-legal studies' "outsider" perspective on law has meant that its proponents have generally focused on concerns different to those of "mainstream" legal scholars. And, finally, there is also the argument that the socio-legal commitment to serious empirical inquiry has encouraged some of its proponents to pass over both theoretical work and doctrinal work.

\section{Socio-legal studies}

In essence, then, what we are suggesting is an exercise in redefinition or reframing so that both socio-legal studies and feminist legal scholarship are accorded new status in "mainstream" debates about law and politics. Given this, it is of interest that, amongst constitutional scholars, there is now increasing attention to quantitative studies of government win-and-loss rates in rights-based judicial review: ${ }^{59}$ these studies provide an important complement to the qualitative work that has tended to dominate this field and they should facilitate better-informed discussion of the alleged counter-

55 Exceptions include Cooper, Governing Out of Order (1998); Millns and Whitty (eds.), Feminist Perspectives on Public Law (1999).

56 For an argument about the relationship that ought to exist between socio-legal research and critical legal theory, see Lacey, "Normative Reconstruction in SocioLegal Theory" (1996) 5 SLS 131.

57 On this issue, and also on the evidence of a "new rapprochement" between comparative lawyers and socio-legal scholars, see Riles, "Casting Off, and Reclaiming, the Weberian Tradition: Comparative Law and Socio-legal Studies" in Zimmerman and Reimann (eds.), Oxford Handbook of Comparative Law (forthcoming 2006). Riles also notes that legal pluralism and non-European comparative law are two areas where there has been a tradition of dialogue between comparativists and socio-legal scholars.

58 See below pp.551-552 and p.554 for discussion of the burgeoning constitutionalist interest in comparative law.

59 Choudhry and Hunter, "Continuing the Conversation: A Reply to Manfredi and Kelly" (2004) 49 McGill LJ 765. It is noteworthy that in the UK context the empirical data on asylum claims continues to be submerged within "administrative law" rather than playing an explicit part in the law/politics debate. But for an exception, see Rawlings, "Review, Revenge and Retreat" (2005) 68 MLR 378. 
majoritarian tendency of rights-based adjudication. More importantly, however, this trickle of interest in quantitative studies opens the possibility of a new, more substantial place for empirical socio-legal work in generating constitutional knowledge. And this possibility is enhanced by the fact that recently there have been a number of calls for more socio-legal work on "constitutional questions": John Dryzek, for example, has emphasised the lack of detailed empirical evidence on issues relevant to the debate over deliberative or discursive democracy, ${ }^{60}$ and in the UK there have been several essay collections ${ }^{61}$ and a number of articles ${ }^{62}$ urging greater attention to the empirical effects of human rights law "in action".

Not surprisingly, we agree with these sentiments: more specifically, we believe that constitutional knowledge (and, by implication, debates about law and politics) would benefit from more empirical work on both the initiation of legal rights claims and the implementation of rights-based rules and judgments. As regards the former issue, socio-legal studies clearly has a great deal to offer in the framing and answering of questions that deserve to be central to debates about law and politics: questions such as "how does a person or a group come to understand a problem in terms of rights?" or "how does a person's identity affect this understanding?" (e.g. is gender a relevant variable in the "turn to law"?). Moreover, socio-legal scholars will be well aware that, in gathering evidence about initiation, there has to be scrutiny of the turn to law outside of courts and legislatures. And, by looking beyond litigation and legislation to the use of commissions of inquiry and the practice of rights-proofing (in both public and private sectors), this work could help to shift the obsession with courtrooms that has gripped so much of contemporary constitutionalism.

We also think that there would be benefits for socio-legal scholars via this framing of their traditional "law-in-action" questions through a law/politics lens: this lens might facilitate a fuller picture of gaps or distortions in current socio-legal work, and it might also provide a mechanism by which to identify or promote emerging projects. On the issue of gaps or distortions, it is for example worth noting that Sally Engle Merry, a US law and society scholar, has expressed concern that, although there is a body of socio-legal literature exploring the contribution of rights talk to social movement activism, relatively little is known about why and when an individual or a vulnerable population adopts rights talk. ${ }^{63}$ And, as regards the argument that a law/politics lens could be a mechanism by which to identify and deepen emerging socio-legal projects, one obvious area of study is surely "legal migration": in other words, the increasing citation, by judges and by other

60 Dryzek, Deliberative Democracy and Beyond: Liberals, Critics, Contestations (2000).

61 Halliday and Schmidt (eds.), Human Rights Brought Home: Socio-Legal Studies of Human Rights in the National Context (2004); Harvey (ed.), Human Rights in the Community: Rights as Agents for Change (2005).

62 Clements, "Winners and Losers" (2005) 32 JLS 34; Thomas and Costigan, "The Human Rights Act: A View from Below" (2005) 32 JLS 51.

63 Merry, "Rights Talk and the Experience of Law: Implementing Women's Human Rights to Protection from Violence" (2003) 25 HRQ 343. 
legal actors, of non-binding sources from other jurisdictions or legal orders. ${ }^{64}$ Constitutional and international law scholars, as well as comparativists, have become deeply interested in this practice. ${ }^{65}$ Should comparative analysis be seen, they inquire, as an embodiment of the marketplace-of-ideas or is the image of a mirror ("something that helps us to see ourselves clearly"66) more apposite? Other approaches call for examination of norms that are not "borrowed" (what Scheppele calls "aversive constitutionalism") and for consideration of what happens to difference if a one-size-fits-all, "comparative-lite" approach to constitutional interpretation takes hold in a range of courts. ${ }^{67}$ All of this suggests to us that the subject of the globalisation of norms requires empirical study by socio-legal scholars. Moreover, although judicial behaviour provides an obvious source of material for such studies, the ways in which legal professionals on the one hand, and social movements on the other, are using global rights norms also deserves greater attention than it has hitherto received. ${ }^{68}$ And these latter studies will need to examine both local actors and international ones because it should not be assumed that they wield sources in an identical manner. ${ }^{69}$

Turning now to the question of implementation: as we see it, the commitment to the ongoing study of implementation that characterises sociolegal studies should be of considerable benefit to debates about law and politics - in particular, it should provide a powerful reminder of the complex relations between law and social change. As mentioned earlier, there seems to be a real need for such a perspective given that rights-based constitutionalism tends to think of law as an autonomous, effective tool of social change and thus focuses almost exclusively on the point at which the law or rule is agreed. Socio-legal studies, by contrast, understands that final rules are elusive and that there is no sense in ending one's inquiries at the point at which a rule is "agreed". Think, for example, of the socio-legal literature on the effects of the US Supreme Court's opinion in Brown v

64 See, e.g. Lawrence v Texas (2003) 339 US 558, where the US Supreme Court majority entered the realm of constitutional borrowing and cited Dudgeon v UK (1982) 4 EHRR 149 to bolster the finding that a Texas statute criminalising homosexual sexual relations was unconstitutional.

65 See generally, McCrudden, "A Common Law of Human Rights?: Transnational Judicial Conversations on Constitutional Rights" (2000) 20 OJLS 499; Booth and Du Plessis, "Home Alone? The US Supreme Court and International and Transnational Judicial Learning" [2005] EHRLR 127.

66 Michelman, "Reflection" (2004) 82 Texas L Rev 1737.

67 See respectively Scheppele, "Aspirational and Aversive Constitutionalism: The Case for Studying Cross-Constitutional Influence Through Negative Models" (2003) 1 Int J of Cons Law 296; Legrand, "Comparative Legal Studies and the Matters of Authenticity", Paper delivered at University of Melbourne, 20 October 2004 [www.law.unimelb.edu.au/alc/assets/legrand_paper.pdf].

68 There is, however, a growing literature in these areas: see, e.g. Hajjar, "Cause Lawyering in Transnational Perspective: National Conflict and Human Rights in Israel/Palestine" (1997) 31 Law \& Society Review 473; Riles, "The Virtual Sociality of Rights: The Case of 'Women's Rights are Human Rights"' in Likosky (ed.), Transnational Legal Processes (2002), pp.420-439.

69 Stychin, "Same-Sex Sexualities and the Globalization of Human Rights Discourse" (2004) 49 McGill LJ 951 makes this observation in contrasting local gay rights activism with international lobby groups. 
Board of Education (1955). ${ }^{70}$ Or of the socio-legal literature on domestic violence, which provides compelling evidence of the problem of "widespread subversion of criminal penalties" and thereby demonstrates that "law is much less effective as sanction than as cultural system" and that "continuous political engagement is necessary to maintain effective legal intervention". ${ }^{71}$ What socio-legal scholars understand - and what rights enthusiasts, in particular, need to appreciate - is that legal rules can be avoided or subverted, that rival interpretations are possible, and that even the most well-intended and carefully-drafted rules can have unexpected adverse consequences. Review of rules is also an unavoidable reality. In sum, as James Tully has reminded fellow constitutionalists, implementation is not so "different in kind to [rule] justification"; it is not, in other words, "simply a technical question of applying rigid rules correctly". ${ }^{72}$ Overall, therefore, our argument is that socio-legal scholarship can provide a powerful challenge to the traditional parameters of the law/politics debate; in particular, it can help to problematise the question of law.

\section{Feminist legal scholarship}

We now want to look at the question of the political: as mentioned earlier, we take the view that although the question of the political features in a great deal of the debate about law and politics (it quite clearly dominates discussions about adjudication), it is generally framed in too limited a form. One way of addressing this problem, we suggest, would be to make greater use of the second source of critical-theoretical work mentioned above: feminist legal scholarship. Specifically, we want to recommend the use of narratival method - both in analysing adjudication and, more broadly, as a tool in constitutional theorising.

Feminist legal scholarship has made a compelling case for the use of narratival method, showing many times over how legal judgments produce and reproduce particular images of women and of men as natural and inevitable. Think, for example, of the feminist work on the ways in which judgments present accounts of good and bad women, and of innocent and less-than-innocent victims. ${ }^{73}$ For present purposes, the key issue is the potential benefits of narratival method for the law/politics debate. This issue has been examined in some detail by the feminist scholar, Joanne Conaghan. In an article analysing Duncan Kennedy's book, A Critique of Adjudication (Fin de Siècle), Conaghan argues that "an adequate understanding of the politics of adjudication demands a broader focus, embracing the role of adjudication not only in determining issues of ideological disagreement but

70 (1955) 349 US 294.

71 Merry, "Global Human Rights and Local Social Movements in a Legally Plural World" (1997) 12 Can J of Law \& Soc 247.

72 Tully, "The Unfreedom of the Moderns in Comparison to Their Ideals of Constitutional Democracy" (2002) 65 MLR 204 at 227. For an account of the response of local housing authorities to judicial review, see Halliday, Judicial Review and Compliance with Administrative Law (2004).

73 See, e.g. Diduck and Kaganas, Family Law, Gender and the State (1999). Scholarship on the construction of sexual legal subjects is equally persuasive on this point: see, e.g. Sandland, "Not 'Social Justice': The Housing Association, the Judges, the Tenant and his Lover" (2000) 8 FLS 227. 
also in defining/reproducing the limits of disagreement". And, in line with this, she calls on Kennedy to consider the following important question: "Why privilege (for purposes of an analysis of adjudication) the role of judges in determining issues that are culturally perceived to be politically contentious .... and neglect the importance of adjudication in constituting and reproducing the politically taken for granted?"74 The same question ought to be put, we suggest, to the many other acknowledged participants in the law/politics debate who have centred their attention on adjudication, thereby encouraging them to adopt a broader stance on the question of the political or, at the very least, to offer an explicit defence of their own starting points.

The prospect of accepted players in the law/politics debate - say, for example, constitutional scholars - adopting, or even being interested in, narratival method may seem far-fetched. But we would argue that this scepticism should be kept in check and, in support of this, we would point to a recent overview of the last 25 years of constitutional theory in which the author, Martin Loughlin, recommends that "[o]ne aim of constitutional theory should be to highlight the ways in which . . . figurative language shapes the way we think about constitutions". ${ }^{75}$ To explain this, Loughlin contrasts two conceptions of a constitution and notes the radically different metaphors attaching to each: on the one hand, the metaphor of mechanism ("checks and balances") and, on the other, evolutionism ("the 'living' constitution"). In so doing, he may well prompt an interest in the use of narratival method amongst constitutional scholars. ${ }^{76}$

Two other important ways in which feminist legal scholarship could enhance the quality of debate on law and politics are as follows. First, amidst increasing interest in comparative constitutionalism and, more broadly, in the migration of legal norms, feminist legal scholarship should help to ensure that studies of the relationship between law "here" and law "there"77 give sufficient attention to the gender impact of comparative and international leanings by domestic judges. At present, for example, we simply do not know whether courts using international law or the constitutional law of other jurisdictions respond differently to legal feminist claims. ${ }^{78}$

Relatedly, there is also clear scope for a new "constitutional" variant on the longstanding feminist engagement with questions of boundary or divide.

74 Conaghan, "Wishful Thinking or Bad Faith: A Feminist Encounter with Duncan Kennedy's Critique of Adjudication" (2001) 22 Cardozo L Rev 721 at 734-5 (our emphasis).

75 Loughlin, "Constitutional Theory: A 25 th Anniversary Essay" (2005) 25 OJLS 183 at 185 .

76 See, e.g. Poole, "Harnessing the Power of the Past?: Lord Hoffmann and the Belmarsh Detainees Case" (2005) 32 JLS 534, analysing the use of judicial myths, historical analogy and nationalist rhetoric by Lord Hoffmann in A and Others $v$ Secretary of State for the Home Department [2004] UKHL 56.

77 The terminology is from Knop, "Here and There: International Law in Domestic Courts" (1999) 32 NYU J of Int Law and Politics 501.

78 For more on this argument, see, e.g. Jackson, "Gender and Transnational Legal Discourse" (2002) 14 Yale J of Law \& Feminism 377. On the approach of the European Court of Justice, see Cichowski, "Women's Rights, the European Court and Supranational Constitutionalism" (2004) 38 Law \& Soc Rev 489. 
Judith Resnik has formulated this new variant in the following way: is jurisdiction gendered ${ }^{79}$ In asking this question, Resnik is calling for closer scrutiny of arguments that particular areas of law "belong" to a particular level of decision-makers (e.g. local rather than national government). Her interest in this issue was prompted by the US Supreme Court's opinion in US v Morrison (2000) ${ }^{80}$ striking down the civil rights remedy in the Violence Against Women Act 1994, which authorised lawsuits in federal courts against those who physically harmed plaintiffs because of their gender. The Morrison court viewed the remedy as a federal entrenchment on lawmaking arenas belonging to the states: "[t]he Constitution", the Chief Justice said, "requires a distinction between what is truly national and what is truly local". Resnik, in responding to this, points out that family law and criminal law areas of law classified as "local" by the Supreme Court - "have long been subjected to federal lawmaking"; in addition, by equating family life with state law, the role played by federal actors "in shaping the meaning of gendered family roles" is hidden from view. ${ }^{81}$ She insists that, whilst "categorical" decision-making cannot be avoided, we ought to cultivate a questioning attitude towards it. In the Chief Justice's words - "truly national", and "truly local" - she finds traces of anxiety, "an effort to make meaningful a division that is not only elusive but increasingly inaccurate . . . [an] attempt to buffer the states from the nation, and [the] nation from the globe". ${ }^{82}$ And, in a comment that resonates very clearly with legal pluralism, she concludes that we need always to remember that "many categories are intertwined in lawmaking enterprises and that more than one source of legal regulation is likely to apply to any set of behaviours". ${ }^{83}$

The other way in which feminist legal scholarship could enhance debate on law and politics is by helping to instill an attitude of greater reflexivity. Contemporary feminist legal scholarship is almost consumed by reflexivity, generated it would seem by the ongoing challenge of facing the immediacy of practical problems whilst being aware of the complex relationship between law and social change. Or from the feeling of being marginal and, at the same time, needing to avoid the trap of being part of a legal feminist orthodoxy. ${ }^{84}$ Or, indeed, from the worry that one's scholarship has "lost its zing". 85 In combination, these experiences and the overriding commitment to reflexivity make feminist legal scholarship very pertinent to the strain of contemporary rights enthusiasm that is impatient with theorists and theorising (and is cosseted by the idea that "[t]here is work to be done, people to be saved ...") and imagines itself to be "innocent of rulership". ${ }^{86} \mathrm{~A}$ commitment to greater reflexivity could for example dislodge the belief, prevalent in certain rights' circles, that law is a terrain of truth or expertise

79 Resnik, "Categorical Federalism: Jurisdiction, Gender, and the Globe" (2001) 111 Yale LJ 619.

80 (2000) 529 US 598.

81 See n.79 at 621 .

82 ibid.

83 ibid., at 622.

84 For discussion, see Bottomley, "Shock to Thought: An Encounter (Of a Third Kind) with Legal Feminism" (2004) 12 FLS 29.

85 Halley, "Take a Break from Feminism" in Knop (ed.), Gender and Human Rights (2004), pp.57-82 at 65.

86 Kennedy, see n.10, at p.332. 
and not one of politics. And, crucially, it could demonstrate to rights' enthusiasts that they are not "innocent of rulership": rather they have power, they make choices and these choices have real, distributional consequences for individuals and groups. ${ }^{87}$

\section{Conclusion}

To recap: the starting point for this article was a feeling of general disquiet about the state of debate in the UK on the relationship between law and politics. Specifically, we noted that the balance between the traditional opposing arguments - that "law is politics", that "law is above politics" - is noticeably askew. We traced this to the fact that the now-extraordinary power of the claim that "law (as rights) is superior to politics" generally faces insufficient challenge or questioning. The largely passive embrace of the previously-shocking claim that "law is politics" is part of the problem. But, in addition, there is the difficulty that, amidst a widespread preoccupation with a particular set of questions about the boundaries of judicial role, neither the question of law nor that of the political seem to be receiving sufficient mainstream attention. The upshot is that the claim that "law (as rights) is above or superior to politics" continues to face only limited scrutiny and this benefits neither rights enthusiasts nor rights cynics, nor indeed anyone else.

Having outlined the problem, we suggested one way to counteract it: namely, there should be a broader definition of what counts as scholarship relevant to questions of law's relationship to politics. Specifically, we proposed that there ought to be a redefinition of the traditional boundaries of the law/politics debate so as to reverse the neglect or under-use of two potentially important resources: first, socio-legal studies and secondly, feminist legal scholarship. As regards socio-legal studies, our argument is that socio-legal approaches which focus on providing empirically-grounded perspectives on the attraction and uses of legal rights claims, and provide an expanded scrutiny of the institutions and cultures where formal legal knowledges are produced, shared, and mediated, merit greater use and acknowledgement in mainstream law/politics debate. As regards feminist legal scholarship, our argument is that both the underlying feminist legal commitment to broadening the concept of the political and the use of narratival method as a key resource could provide an important check on the tendency to base the law/politics divide on a traditional understanding of what is (and, by implication, what is not) politically-contentious. More generally, the emphasis within feminist legal scholarship on the need for reflexivity - as regards assumptions about what counts as feminist legal scholarship, about what should be studied, and about the theories and techniques that are used - deserves to be seen as an exemplar for scholarly engagement with rights.

87 ibid., at p.350. 